\title{
USGS Permafrost Research Determines the Risks of Permafrost Thaw to Biologic and Hydrologic Resources
}

The U.S. Geological Survey (USGS),

in collaboration with university,

Federal, Tribal, and independent partners, conducts fundamental research on the distribution, vulnerability, and importance of permafrost in arctic and boreal ecosystems. Scientists, land managers, and policy makers use USGS data to help make decisions for development, wildlife habitat, and other needs. Native villages and cities can forecast landscape change and where soils are vulnerable to thaw with more certainty. The scientific community can use USGS data to develop scenarios of future permafrost change.

\section{What is Permafrost?}

Permafrost is frozen ground that underlies a quarter of the Northern Hemisphere; it defines the landscape and landscape processes of the Arctic. Permafrost helps retain surface water in ecosystems rather than allowing it to flow away. In so doing, it modifies water availability and thus helps dictate the distribution of plants and animals. Permafrost is also critical in maintaining the physical structure of soils, so that houses and roads can be built on them. In addition, permafrost maintains ecosystem integrity: ecosystems with stable permafrost may be less susceptible to disturbances such as wildfire and erosion.
What happens when permafrost thaws? Continued atmospheric warming is expected to thaw permafrost over large regions this century. During thaw, the flow and interaction of surface water and groundwater change, making some systems wetter and others drier. Rates of erosion and landslides can increase, and land can subside, transforming ecosystems. Permafrost also contains enormous quantities of soil organic matter that has been frozen for tens of thousands of years. When permafrost thaws, soil organic matter is decomposed by microorganisms, reducing soil carbon storage, increasing greenhouse gas emissions, and affecting soil nutrients and water quality.

Shoreline erosion near Drew Point, north coast of Alaska. Photograph by Ben Jones, U.S. Geological Survey.

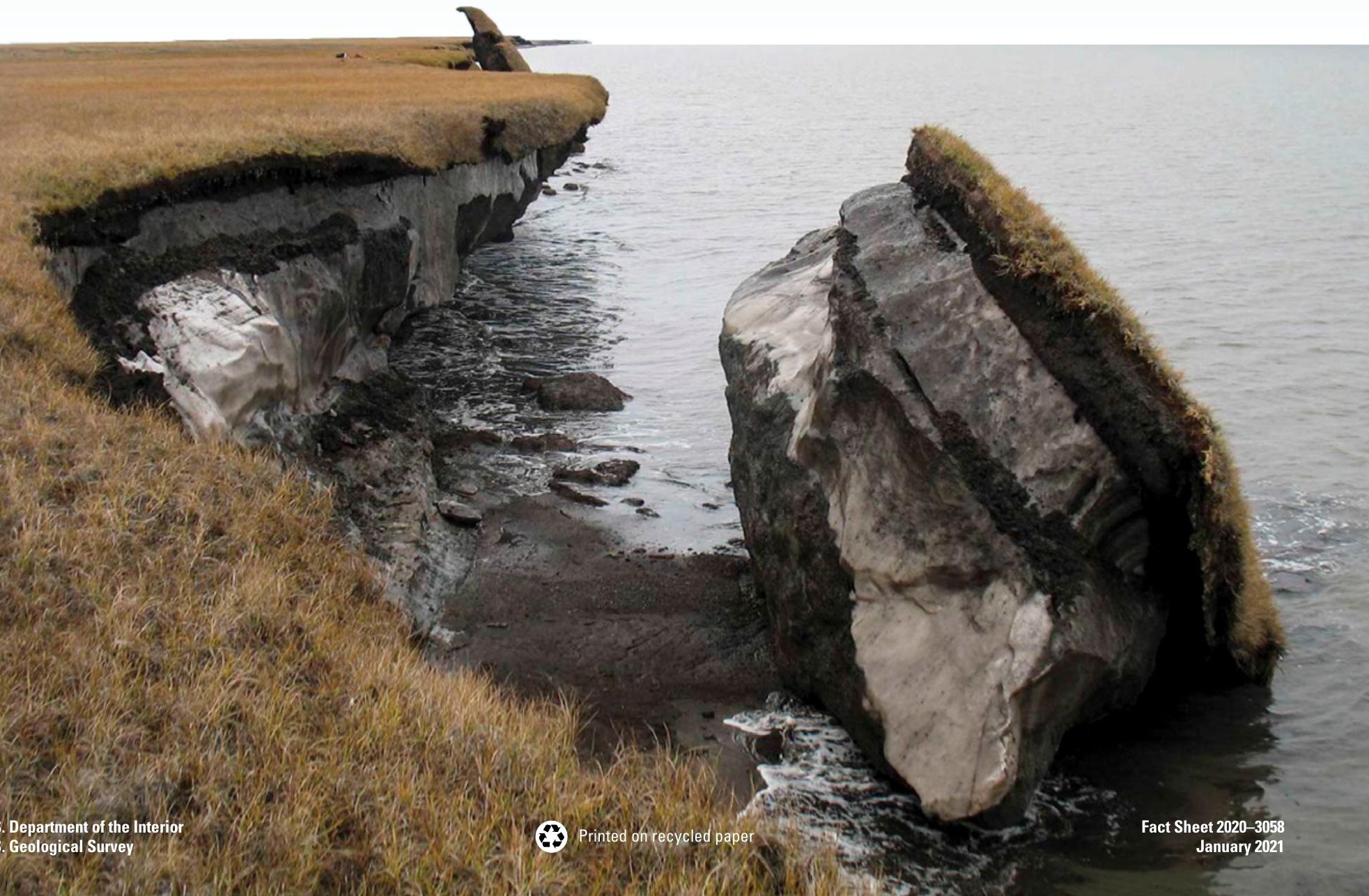




\section{Permafrost-Remnants of Ice Ages Past}

Permafrost can act as a physical record of past landscape processes, recording how sediment, plant remains, and ice have accumulated with time. USGS researchers use information from cores of permafrost, wetland soils, and lake sediments to identify when in the past permafrost formed and degraded. For example, clues from age dating plant tissues or minerals in the cores improve our understanding of climate history. Using these methods, researchers have determined that some of the oldest permafrost formed during the Pleistocene, as much as 700,000 years ago. In some locations, however, permafrost only formed within the last few thousand years (the late Holocene), when high-latitude temperatures cooled. Permafrost soils often have high carbon and ice content, and their remobilization upon thaw has major implications for greenhouse gas production and the distribution of water in ecosystems. By better understanding permafrost history, scientists can determine robust scenarios of climate change impacts on ecosystems.

\section{Detecting Permafrost Change}

Understanding changing permafrost conditions in the Arctic is essential for land-use planning, environmental assessments, and a wide-array of societal concerns. The changing nature of permafrost can be quantified by air- and spaceborne remotely sensed imagery, geophysical techniques, deep temperature probes (borehole data), and active layer monitoring (the active layer is the surface soil that thaws and refreezes annually).

Using historical maps, aerial and satellite photographs, and remotely sensed elevation data, USGS scientists measure how the coastal Alaskan shoreline has changed since the 1940s. Although both erosion and deposition occur, in some areas erosion rates were as much as 22 meters ( 72 feet) per year. Thawing permafrost, in addition to the loss of sea ice, enhances coastal erosion and can profoundly impact coastal communities.

Changes in lake area resulting from permafrost thaw are also mapped by remote sensing methods. Lakes that have formed from thawed permafrost are known as thermokarst

Map of near-surface (within 1 meter [ 3 feet]) permafrost in Alaska, as determined from field and remote sensing data. Inset, circum-Arctic map of permafrost extent. Map data compiled by Pastick and others (2015) and Brown and others (2014).

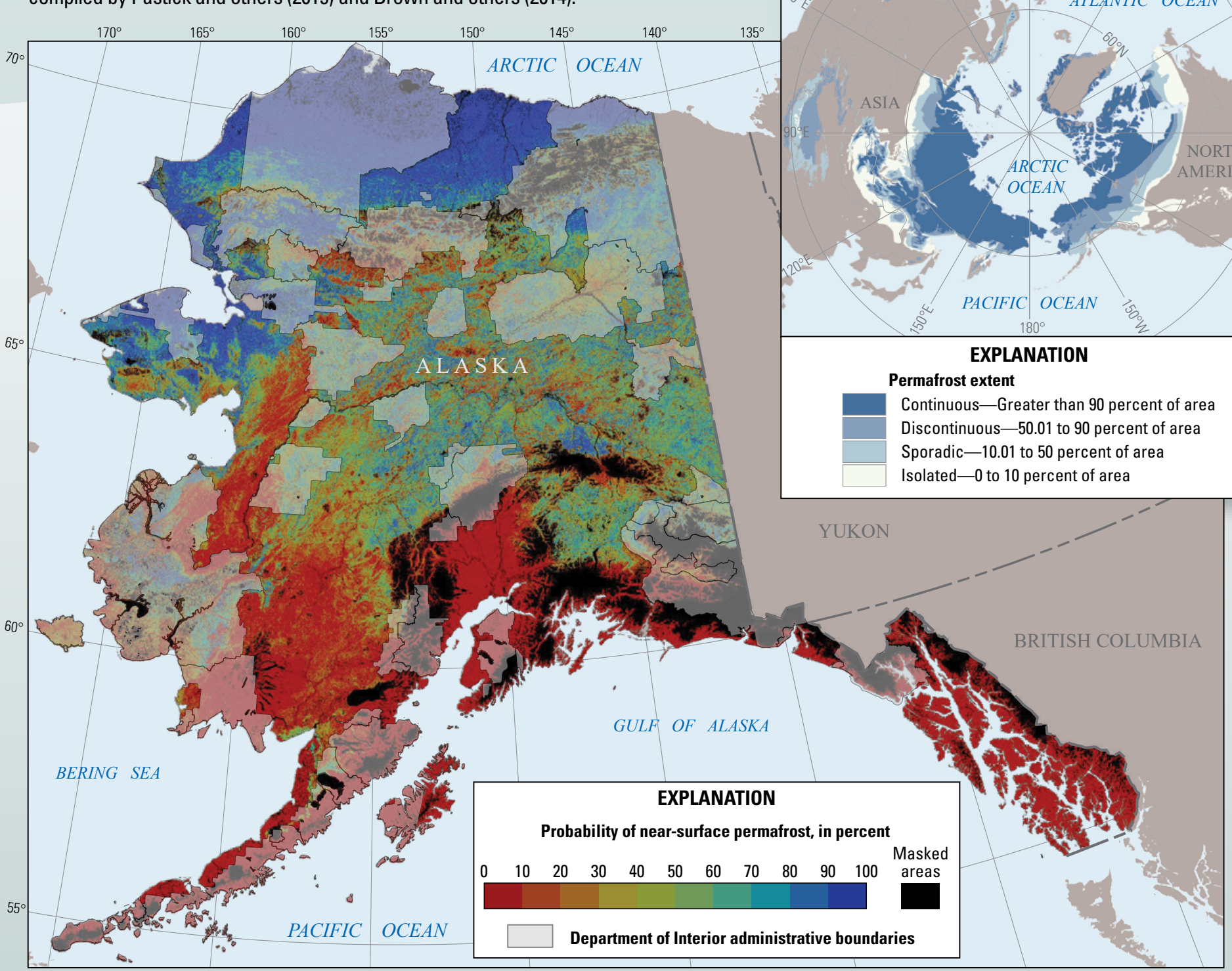


lakes and are signature features of Alaskan landscapes. Thermokarst lakes undergo an evolution over thousands of years, expanding from small thawed permafrost depressions to larger lakes over time, and then, in many cases, lake drainage. In the Yukon Flats, a lowland river floodplain of sub-Arctic Alaska, approximately 1 in 10 lakes shrank between the 1980s and 2014, before heavy precipitation in and after 2015 led to lake-level recovery. A similar pattern was seen statewide, where national wildlife refuges lost 0.8 percent of lake area per year before 2015 .

Scientists at the USGS are also experts at examining permafrost properties without disturbing the ground by using geophysical measurement techniques that can detect into the earth without the need for drilling - similar to taking an $\mathrm{x}$-ray without the need for surgery. For example, airborne electromagnetic (AEM) data provide a snapshot of permafrost and soil properties to depths greater than 100 meters ( $>300$ feet) and is collected from an aircraft that can easily cover large and remote areas. In the Yukon Flats, USGS scientists used AEM data to map the distribution of permafrost in relation to lakes, ponds, and rivers. For

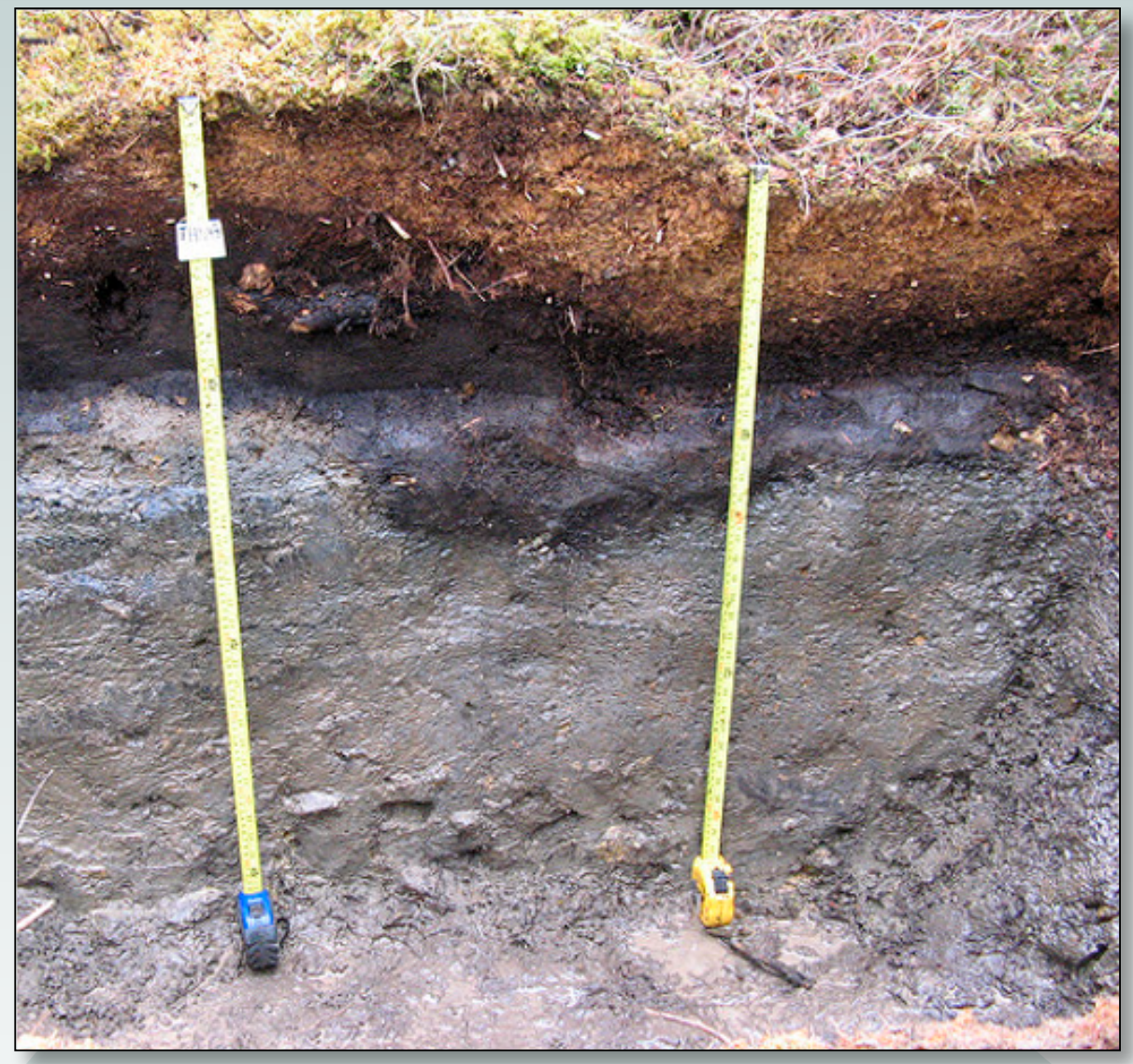

Photograph of the top meter of soil, showing the active layer underlain by permafrost. Permafrost is often grey to black as a result of the high organic content and low oxygen availability in frozen soils. Photograph by J. O’Donnell, National Park Service, used with permission.

Map showing rates of coastal erosion in Alaska derived from field surveys and remote sensing. Permafrost thaw can accelerate erosion, which can be more than 5 meters (16 feet) per year. Map data compiled from Gibbs and Richmond (2015) and Gibbs and others (2019).

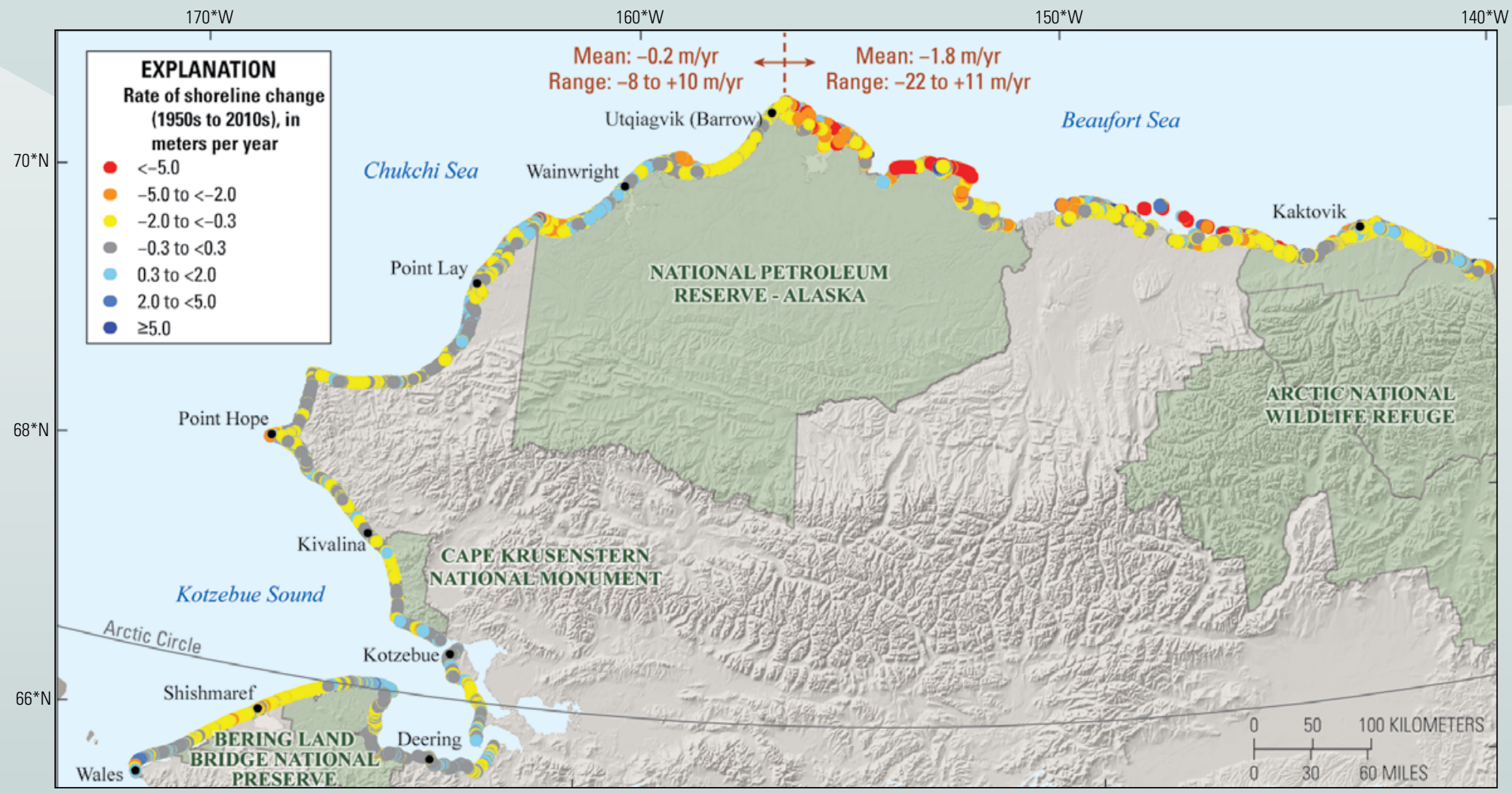

Base from U.S. Geological Survey 300-meter digital elevation model 
water bodies that do not freeze completely in winter, the underlying sediment remains unfrozen and can sometimes form a pathway connecting surface water with deeper groundwater systems that may play a role in the patterns of lake shrinkage and expansion described above. Although airborne geophysical data help rapidly map permafrost over large areas, USGS scientists also use ground-based geophysical measurements to detect and monitor permafrost change at smaller scales where more detailed observations are needed.

\section{The Necessity of Long-Term Field Experiments to Understand Variability and Change}

Long-term monitoring is essential for understanding many of the processes that control permafrost thaw and landscape change. USGS researchers maintain many long-term field monitoring sites in Alaska to document changes in permafrost conditions and how that impacts ecosystem processes.

Changes in the physical condition of permafrost translates into changes in the movement of carbon and nutrients, which affect important natural resources such as forests, wetlands, lakes, streams, and rivers. In many of these systems, permafrost carbon, once thawed, is released as greenhouse gas, leading to further buildup of these gases in the atmosphere. Through field studies that span years to decades, researchers are examining changes in permafrost temperatures, physical stability, greenhouse gas production, and changes in other ecosystem processes. New technologies, such as drone-mounted greenhouse gas sensors, laser spectrometers, and geophysical instruments allow researchers to characterize thaw processes and greenhouse gas fluxes in better detail. Macrofossil, pollen, and environmental DNA (eDNA) helps researchers learn about the history of plant and microbial communities from permafrost and how microbes in frozen environments contribute to carbon and nutrient cycles.

Permafrost thaw changes the movement of water and solutes through soils, because after thawing water can move more easily through unfrozen soil. Therefore, carbon, nutrients, microbes, and contaminants that were frozen into permafrost soils for thousands of years are released to the environment, where they are transformed or transported to surface waters. These changes affect entire ecosystems through food webs. For example, mercury is a neurotoxin that becomes concentrated in permafrost. The release of stored mercury is a substantial risk to human health and food supplies. USGS scientists estimate the amount of mercury stored in permafrost in the Northern Hemisphere is double the amount found in non-permafrost soils, the atmosphere, and the oceans combined.
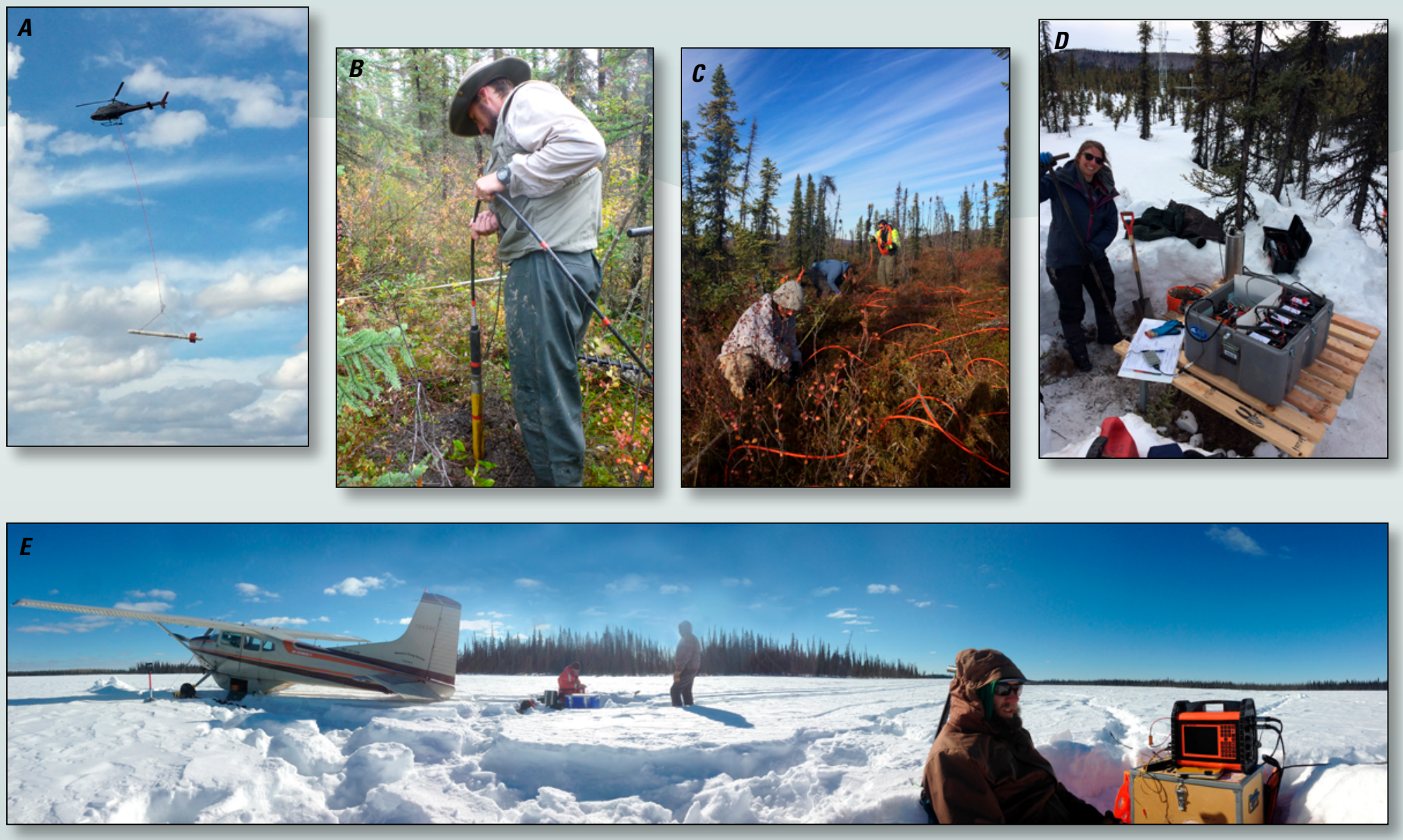

U.S. Geological Survey (USGS) researchers collect geophysical data using airborne, ground-based, and borehole sensors to characterize and monitor the state of permafrost over different spatial scales. Measurements used include airborne electromagnetic surveys $(A)$ that map subsurface permafrost over large areas without the need for ground access, nuclear magnetic resonance $(B)$, electrical resistivity tomography $(C)$, ambient seismic tomography $(D)$, and time-domain electromagnetic measurements (E). Photographs by Burke Minsley, USGS $(A-D)$ and David Rey, USGS (E). 


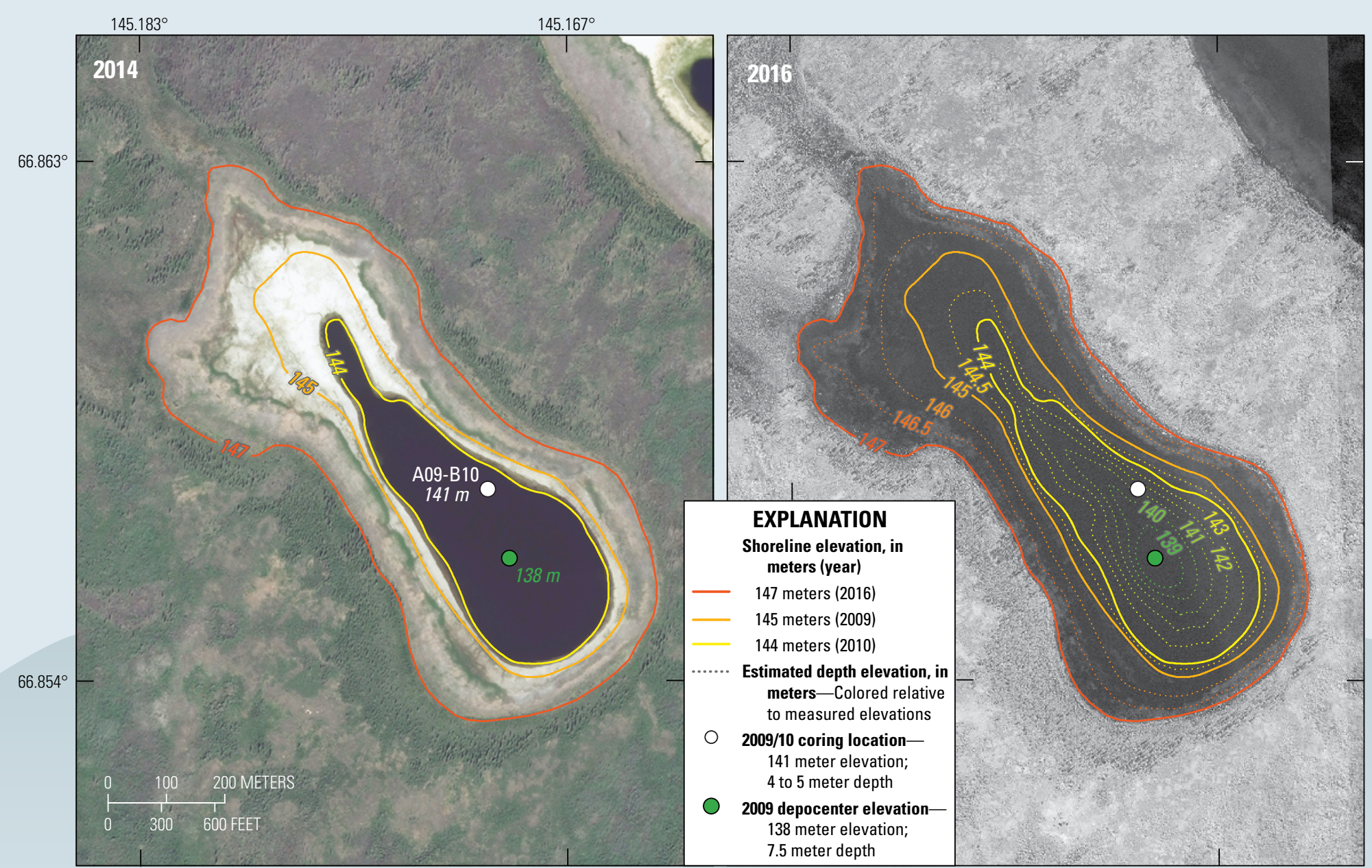

Track Lake is a thermokarst lake located in the Yukon Flats National Wildlife Refuge in northern interior Alaska. Imagery from Digital Globe Worldview-2 shows historic high (July 2016) and low (April 2014) lake levels (black areas). The sediment record in this lake documents 4,500 years of lake level variations. Figure modified from Anderson and others (2018).

\section{Monitoring Changes to Animal and Plant Communities}

Thawing permafrost affects northern wildlife and their habitats, often by changing the size of waterbodies and their distribution on the landscape. The redistribution of water will benefit some species but will reduce the success of others. The rapid rate of change challenges our ability to make predictions and properly manage lands and resources. For example, the shorelines of shrinking lakes are quickly filled in by diverse, productive wetland plant communities, but over time these wetlands may be submerged again. Northern lakes and wetlands provide valuable breeding habitat for migratory waterfowl, but shifting lake and wetland sizes alter local biodiversity. Permafrost thaw on the arctic coastal plain of Alaska has encouraged saltwater flooding and the growth of salt-marsh wetlands that provide high-quality goose habitat, supporting an expanding population of Snow Geese. Wildlife can also affect permafrost degradation, as demonstrated by the creation of thermokarst lakes and ponds in parts of the Arctic where beaver populations have altered the landscape.

\section{Working with Indigenous Communities}

USGS scientists collaborate with Tribal environmental professionals in Alaskan Native villages, Canadian First Nation communities, and Indigenous nonprofit organizations to monitor permafrost as part of community-based research. Interviews are conducted to integrate local and Indigenous observations and knowledge of landscape change into our understanding of permafrost thaw and its impact on communities. Permafrost thaw resulting in ground collapse and changing lake size, water availability, wildfire behavior, and plant and animal resources have all been documented.

USGS facilitates the sharing of information and data with Indigenous communities and local, national, and international governments and organizations through written community reports, oral presentations, and online resources.

\section{Contributing USGS Science Centers and Disciplines}

USGS permafrost research transcends multiple programs, science centers, and disciplines. These centers include the Geology, Minerals, Energy, and Geophysics Science Center, the Florence Bascom Geoscience Center, the Earth Resources Observation and Science Center, the Water Mission Area, the Geology, Geophysics, and Geochemistry Science Center, the Alaska Science Center, the Pacific Coastal and Marine Science Center, and the Geoscience and Environmental Change Science Center. 


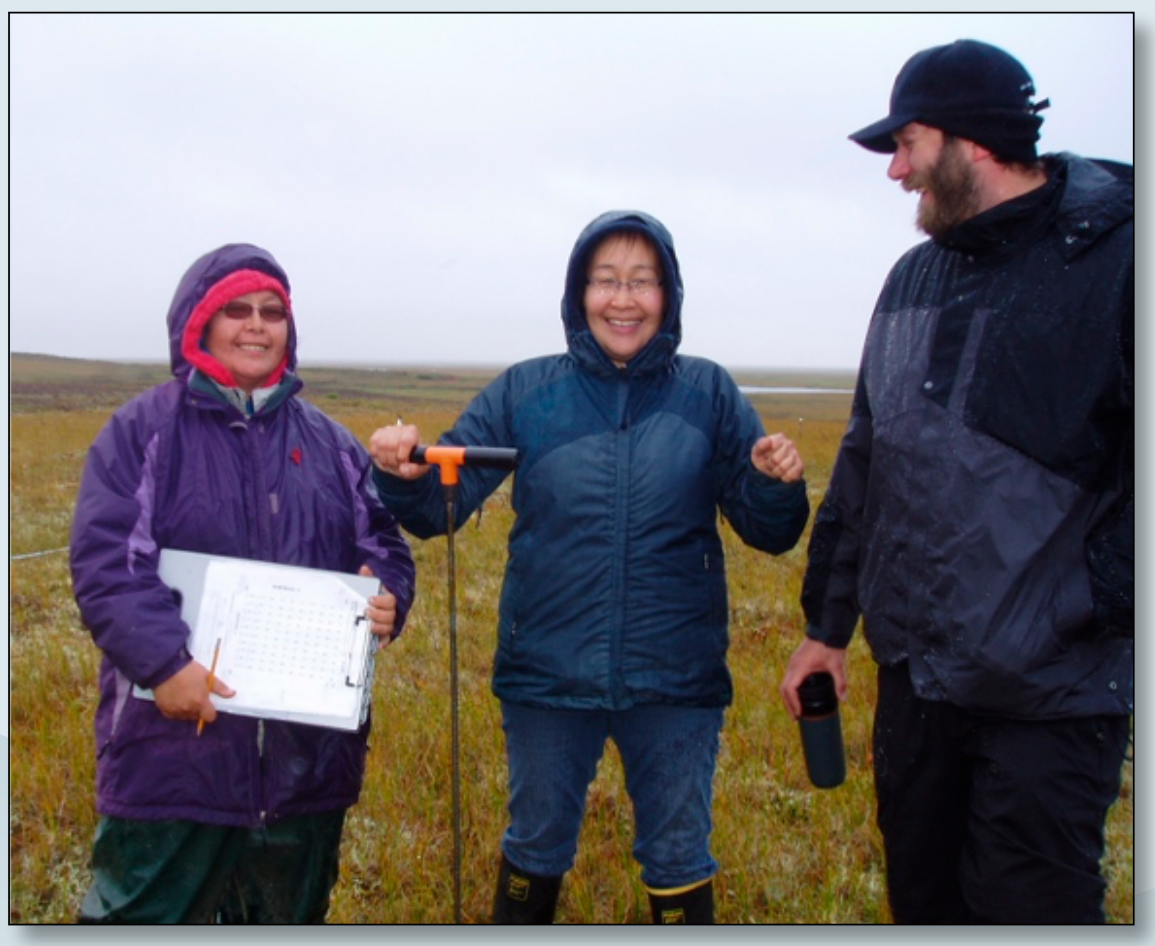

Tribal environmental professionals from the Indigenous Observation Network (ION) work with U.S. Geological Survey researchers to monitor permafrost thaw and water quality. Photograph by Nicole Herman-Mercer, U.S. Geological Survey.

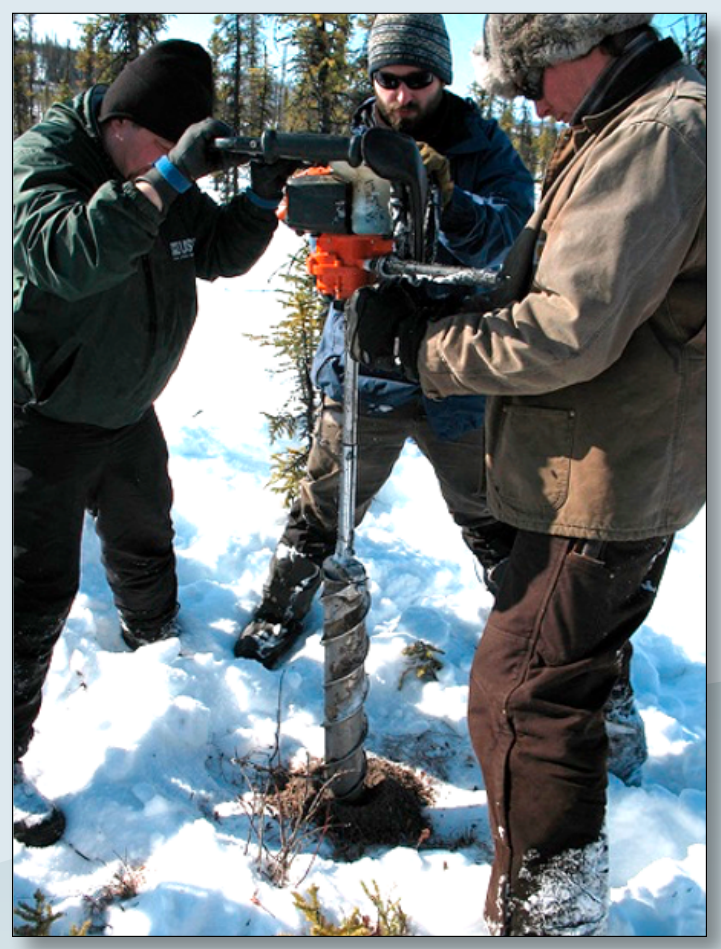

U.S. Geological Survey researchers drill permafrost cores, which are used to quantify carbon storage and other permafrost attributes. Photograph by K. Wickland, U.S. Geological Survey.

\section{References}

Anderson, L., Finney, B.P., and Shapley, M.D., 2018, Lake levels in a discontinuous permafrost landscape-Late Holocene variations inferred from sediment oxygen isotopes, Yukon Flats, Alaska: Arctic, Antarctic, and Alpine Research, v. 50, no. 1. [Also available at https://doi.org/10.1080/15230430.2018.1496565.]

Brown, J., Ferrians, O., Heginbottom, J.A., and Melnikov, E., 2014, Circum-Arctic map of permafrost and groundice conditions, version 1: National Snow and Ice Data Center web page, accessed April 10, 2020, at https://doi. org/10.7265/8d57-9f79.

Gibbs, A.E., and Richmond, B.M., 2015, National assessment of shoreline change-Historical shoreline change along the north coast of Alaska, U.S.-Canadian border to Icy Cape: U.S. Geological Survey OpenFile Report 2015-1048, 96 p. [Also available at http:// dx.doi.org/10.3133/ofr20151048.]

Gibbs, A.E., Snyder, A.G., and Richmond, B.M., 2019, National assessment of shoreline change-Historical shoreline change along the north coast of Alaska, Icy Cape to Cape Prince of Wales: U.S. Geological Survey Open-File Report 2019-1146, 52 p. [Also available at https://doi.org/10.3133/ofr20191146.]

Pastick, N.J., Jorgenson, M.T., Wylie, B.K., Nield, S.J., Johnson, K.D., and Finley, A.O., 2015, Distribution of near-surface permafrost in Alaska_-Estimates of present and future conditions: Remote Sensing of Environment, v. 168, p. 301-315. [Also available at https://doi. org/10.1016/j.rse.2015.07.019.]

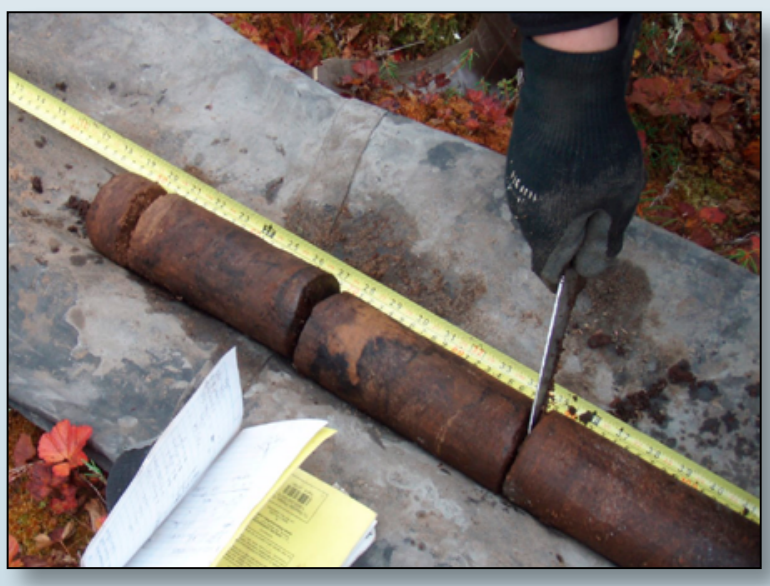

A drilled permafrost core is segmented by hand in the field before being transported to laboratories for analysis. Photograph by Jennifer Harden, U.S. Geological Survey.

By Mark P. Waldrop, Lesleigh Anderson, Mark Dornblaser, Li H. Erikson, Ann E. Gibbs, Nicole M. Herman-Mercer, Stephanie R. James, Miriam C. Jones, Joshua C. Koch, Mary-Cathrine Leewis, Kristen L. Manies, Burke J. Minsley, Neal J. Pastick, Vijay Patil, Frank Urban, Michelle A. Walvoord, Kimberly P. Wickland, and Christian Zimmerman

Edited by Katherine Jacques

Layout and design by Cory Hurd

For more information, contact:

Alaska Regional Director,

4210 University Drive, Anchorage, AK 99508

907-786-7091 